\title{
The diversity of AnCient Greek through the eyes OF A FORGOTTEN GRAMMARIAN.
}

\author{
Petrus Antesignanus (CA. 1524/1525-1561) \\ ON THE NOTION OF "DIALECT"*
}

\section{Raf Van Rooy}

KU Leuven \& FWO

\section{Résumé}

Les idées linguistiques du grammairien français Pierre Davantès $\left(\mathrm{XvI}^{\mathrm{e}}\right.$ siècle) ont été largement négligées jusqu'à aujourd'hui. La présente contribution cherche à combler partiellement cette lacune de recherche dans le contexte de la notion de " dialecte ». Après une introduction succincte à la vie et à l'œuvre de Davantès, sa conception de dialecte est discutée, conception qu'il expose dans ses scholies de 1554 à la grammaire grecque de Nicolas Clénard. L'analyse se fait à la fois d'une façon générale et spécifiquement par rapport à la situation grecque ancienne. Ensuite, cette contribution contextualise les idées de Davantès. L'attaque d'Henri Estienne contre les assertions de Davantès est conçue comme une étude de cas à cet égard.

\section{Mots-clés}

Dialecte, dialectologie, grec ancien, grammaire, Pierre Davantès

\section{Abstract}

The linguistic ideas of the 16th-century French grammarian Petrus Antesignanus have been largely neglected up till now. In the present paper, I aim to partially repair this research lacuna within the context of the notion of "dialect". After some short introductory notes on Antesignanus' life and works, I discuss his conception of dialect, which is expounded in his 1554 scholia on Nicolaus Clenardus' Greek grammar. This analysis occurs both on a general level and specifically with regard to the Ancient Greek situation. I include in this discussion a number of considerations that contextualize the views of Antesignanus. Henricus Stephanus' attack on Antesignanus' assertions figures as a case study in this regard.

\section{Keywords}

Ancient Greek, dialect, dialectology, grammar, Petrus Antesignanus

* The present contribution serves as a first case study that anticipates some of the results of my research into the early modern "dialect" concept and its relationship to the notion of "language" (funded by the Research Foundation - Flanders (FWO)). I kindly thank Pierre Swiggers and Toon Van Hal for their many critical and valuable remarks. I am also much indebted to the useful suggestions of the three anonymous reviewers. I thank Yves Duss for correcting the French of my abstract. 
In the present paper, I aim to analyze and contextualize the linguistic views of the French scholar Petrus Antesignanus, especially with regard to the notion of "dialect". I argue that this overlooked 16th-century grammarian was one of the first influential Western theorizers of the concept in question. As often in the early modern era, he discussed it against the background of the prototypical Ancient Greek situation. ${ }^{1}$

The biographical information about Antesignanus serves as an introduction (1.). Then, the way in which he conceived of the dialect notion takes center stage (2.). Next, I consider the role of the Ancient Greek background, which clearly triggered his observations (3.). Indispensable within this regard is a contextualization of Antesignanus' views, with special attention to Henricus Stephanus' twofold attack on his assertions (4.). Sections 2.-4. have the following structure: after briefly discussing the relevant research questions, I analyze and reconstruct Antesignanus' ideas (both explicit and implicit). I conclude this contribution with some general notes and an outlook (5.).

\section{Petrus Antesignanus: a forgotten scholiast of Nicolaus Clenardus' Greek grammar}

Petrus Antesignanus (the Latin alias of Pierre Davantès "the older") ${ }^{2}$ was a Protestant philologist, grammarian, and musicologist, born ca. 1524/1525 in Rabastens-deBigorre, an Occitan village some $40 \mathrm{~km}$ north of Lourdes and $120 \mathrm{~km}$ west of Toulouse. There has been an intense, ideologically colored discussion about the native town of Antesignanus. Marty (1896) offers a "definitive" answer to this question. Although he originates from Rabastens in the Tarn department, he "has done away with every personal sentiment for the sake of the historical truth" and confirms that Antesignanus was born in Rabastens-de-Bigorre in the Hautes-Pyrénées department. ${ }^{3}$

1 Cf. Haugen (1966, p. 923): "The linguistic situation in ancient Greece was both the model and the stimulus for the use of the term [sc. "dialect"] in modern writing."

2 See Bayle (1740, p. 243-244), Haag \& Haag (1886, p. 163-170), Hayaert (2008, p. 46), and Schwarzfuchs $(2008$, p. 27) for most of the relevant biographical information mentioned in this section. For his Latin alias meaning "he who fights before the standard" and its link with Middle French davantié ("celui qui marche en avant"), see Hayaert (2008, p. 46). His Hel-

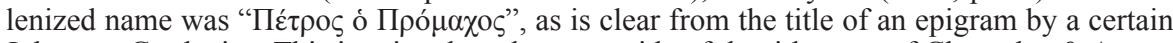
Johannes Gardegius. This is printed on the verso side of the title page of Clenardus \& Antes-

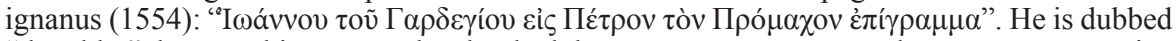
"the older", because his younger brother had the same name. Davantès the younger was active as a bookseller and printer in Geneva (in the period 1561-1573; for this information, see the entry "Davantès le Jeune" in the R.I.E.C.H online database and Chaix 1954, p. 166). Their father was Je(h)an des Davantès (called "de La Hélète"; see Marty 1896, p. 347).

3 See Marty (1896, p. 346 \& p. 351) and Haag \& Haag (1886, p. 163). What is more, even in Marty's time there were people called "Davantès" living in Rabastens-de-Bigorre, whereas no one of that name turns up in the records of Rabastens in the Tarn department (Marty 1896, p. 351). The Latin adjective Rapistagnensis, which is often included in the titles of Antesignanus' works (e.g., in Clenardus \& Antesignanus 1554), is inconclusive in this respect. 
In the 1740 edition of Pierre Bayle's (1647-1706) Dictionnaire historique et critique, Antesignanus is called "one of the best grammarians of the 16th century" ("un des meilleurs Grammairiens du XVI ${ }^{e}$ siècle") $)^{4}$ and characterized as a patient editor of Terence who preferred anonymity to the risk of being envied by rivals (to which the oblivion he sank into still testifies today). Apart from Latin and Greek, he also mastered Hebrew. He even wrote a relatively long letter in this language, which is printed in Costus (1554, p. $\mathrm{X}-\mathrm{T}$, inserted between p. 59 \& p. 65) and recommends the booklet in question (see Haag \& Haag 1886, p. 163 and Hayaert 2008, p. 96). He taught these three biblical languages in Lyon (between ca. 1554 and 1559). This is confirmed by the dedicatory letter in his first edition of Terence (dated August 13, 1556 and addressed to three brothers he tutored). Before that, Antesignanus appears to have studied in Avignon for some time. In March 1559, he moved to Geneva, where he started printing books and undertook most of his musicological activity (see his edition of the "Psalms of David", published in 1560, and Chaix 1954, p. 165-166). Antesignanus died there on August 31, 1561, only 36/37 years old. His death is mentioned in a letter from John Calvin (1509-1564) to Theodore Beza (1519-1605), dated September 3, 1561 (see Haag \& Haag 1886, p. 164).

Antesignanus' major writings on Ancient Greek are (1) the scholia on Nicolaus Clenardus' widely used grammar, (2) the Praxis seu usus praeceptorum grammatices, and (3) the De thematis uerborum et participiorum inuestigandi ratione libellus, the three of which are generally edited together with Clenardus' grammar. The 1554 editio princeps of this collection was printed in Lyon. It did not yet include text (3), which first figures in the second edition (Lyon 1557, p. 321-414). All of these works by Antesignanus are only briefly mentioned by his biographers-a negligence that is continued in the historiography of linguistics. For our purposes, the commentary on Nicolaus Clenardus' (Nicolaes Cleynaerts; 1493/1495-1542) Greek grammar, entitled Institutiones in linguam Graecam and first published in 1530, is most important. ${ }^{5}$ The scholion that especially concerns us here bears the title "De dialectis appendix" (1554, p. 11-16) and follows Clenardus' brief reference to the Greek dialect situation. ${ }^{6}$ This passage will constitute the core of the discussion.

4 See Bayle (1740, p. 243); Antesignanus is praised for being concerned with the most basic grammatical issues (as is clear from the preface to his first Terence edition, i.e. 1556, p. ${ }^{*}$ ijr*ijv): "Il prit tellement à cœur son métier, qu'il aima mieux se rendre utile à la jeunesse en s'attachant à l'explication des choses qui embarassent la prémiere entrée des études, que de chercher de la gloire par l'explication des grandes difficultez." I have preserved the original orthography in quoting early modern French texts.

5 For more information about this well-known Humanist from Diest (nowadays Belgium) and his Greek grammar, which dominated the teaching of Ancient Greek for centuries, see, e.g., Hoven (1993) and Swiggers \& Van Hal (2009).

6 See Clenardus (1530, p. 7): "Quinque Graecorum linguae praecipuae, communis, Attica, Ionica, Dorica, Aeolica. E quibus Attici in omni declinatione uocatiuum similem formant nominatiuo, ò et $\tilde{\omega}$ Aiveías." 


\section{THE CONCEPTUAL COMPONENT: DIALECT AND RELATED NOTIONS}

The central question in analyzing Antesignanus' notion of dialect boils down to "how is the term dialectus defined, paraphrased, approached, and/or used?". An important methodological caveat is in order here: we have to be careful not to project our own presuppositions on his theorizing. In addition to this, the present section reveals with which linguistic concept(s) Antesignanus contrasted or associated the dialect notion and which criteria he took into account in defining it. I also point out on which (linguistic) level(s) dialects vary in Antesignanus' view and how the conceptual discussion is encoded terminologically.

To start with, Antesignanus (1554, p. 12-13) defines dialectus as follows:

Itaque [...] grammatici per dialectos, idiomata siue linguas, nihil aliud intelligunt, quam sermonis quandam proprietatem, qua distinguitur loquelae uarietas, quae semper solet contingere inter diuersos eiusdem nationis tractus; cum hi paulo aliter loquantur quam illi ac cuique proprium quidpiam e natali solo sit insitum; quod, si bene auribus sonare uideatur, alii quoque usurpare gaudent et quod uni urbi aut nationis paruo tractui proprium erat ac peculiare, aliquo temporis interuallo in communem linguam transfundunt; atque ita illam ditant ex diuersis uariorum tractuum proprietatibus, quae insigne quiddam et auribus gratum continebant.

Therefore [...] grammarians mean by "dialects", "idioms", or "languages" nothing else than a certain property of speaking, by which the variety of speech is distinguished. This usually occurs between different regions of the same people, because some speak a little differently from others and something proper from the native soil is engrafted in everyone. But if this would seem to sound good to the ears, others also take pleasure in using it. And after a while, they decant to the common language an element that was proper and peculiar to one city or to a small territory of the people; and this way they enrich it by drawing on diverse properties of various regions, which comprised something remarkable and pleasant to the ears. ${ }^{7}$

He clearly focuses on the Greek concept ("quid Graeci intelligant" \& "grammatici [...] intelligunt"; Antesignanus 1554, p. 11 \& 12; see Van Rooy 2016), which was not yet entirely integrated into the Humanist conceptual apparatus of his time and which he claims to have been understood wrongly by Clenardus' opponents. Even though he mainly uses the term dialectus in the sense of "language variety particular to a certain region of one nation", the aforementioned passage shows that idioma and lingua can also be used in this specific meaning. ${ }^{8}$ Rather than contrasting dialectus to lingua (which can be synonyms), he opposes the concept of "language variety particular to a certain region of one nation" to the notion of "common language" (lingua communis). The former is characterized by being typical of a certain

7 All English translations in the present contribution are mine. I have also uniformized Latin orthography, while preserving the Greek spelling of the early modern sources. All Greek and Latin abbreviations are expanded. Punctuation in Latin quotes is adapted to modern conventions.

8 For this meaning, the term dialectus seems to have provided the unambiguity Latin terms such as sermo, lingua, loquela, and uarietas lacked. 
ethnic group (ethnic criterion) ${ }^{9}$ and geographic location (diatopic criterion), and by exhibiting a relative particularity that distinguishes it from other varieties of the same language. Moreover, this speech form serves as a kind of identity mark, revealing the provenance of a speaker, something which is difficult to dissimulate entirely..$^{10}$ Antesignanus also introduces the notion "mother/native dialect" ( $m a$ terna dialectus), which is represented as a source of pride for Greek poets, who mix it with features of the "common language".

The common language has a wider communicative reach. ${ }^{12}$ After all, it is said to be the variety common to the speakers of the different dialects. However, the precise relationship between the dialecti and the communis lingua remains somewhat unclear. Other kinds of intralingual variation (not termed dialectus) are also alluded to. Antesignanus mentions diaphasic and diastratic variation in French and Greek. The jargon of lawyers is contrasted with "actorish" language (diaphasic) and is said to imitate speech with higher social status, whereas actors indulge in staging diastratically lower speech varieties:

Vt hodie Lutetiae uidere licet fabularum actores, ut risum auditorum captent, uti sermone muliercularum, a communi Gallico nonnihil degenerante; nam $r$ in s non raro commutant reliquasque litteras blaese ac compressis labiis enuntiant. Patroni uero, qui in foro causas agunt, quamuis pure ac proprie loqui studeant et aliquid ex Lutetiano sermone decerpant nonnihilque ex Aureliano, ubi forte legibus operam nauarunt, ac rursus aliquid ex huius uel illius celebris ciuitatis idiomate, praecipue uero e Regis domesticorum sermone depromptum; cauent tamen maxime, ne muliercularum more loqui uideantur. Si enim illarum sermonem imitarentur, fabula omnibus essent maximoque risu ab auditoribus exciperentur. Confer nunc Demosthenis orationem cum ea, qua utuntur hodie patroni in foro Parisiensi; Aristophanis uero comoedias cum fabulis illorum histrionum, qui agendo sermonem Lutetianae plebeculae familiarem repraesentant. (Antesignanus 1554, p. 12)

In contemporary Paris it is possible to see that actors of plays, in order to arouse the auditors' laughter, use the speech of foolish women, which degenerates somewhat from common French. For they do not rarely change the $r$ into s and pronounce the remaining letters lispingly and with squeezed lips. Lawyers, however, who pursue lawsuits in public, are eager to speak purely and properly; and they may

9 See also Antesignanus (1554, p. 11): "Fuerunt uero et aliae multae, tot scilicet quot fuerunt nationes, quae Graeco sermone uterentur, ueluti Boeotica, Sicula, Rhegina, Cretensis, Tarentina, Cypria, Chalcidica, Macedonica, Argiua, Thessala, Laconica, Syracusana, Pamphylica; [...].”

10 See Antesignanus (1554, p. 11): “[...] ut iudicatu difficile non sit (si quis eos loquentes audiat, uel eorum scripta legat) ad quod idioma illorum sermo accedat. Vix enim fieri potest, quin aliquid e propria siue materna lingua retineant, etiam illis inuitis, ac Gallica lingua loqui nitentibus; [...]."

11 See Antesignanus (1554, p. 13): "Nos uero in his Scholiis non solum quae ab oratoribus et communi usu ex uariis idiomatibus recepta sunt, annotabimus, sed ea etiam quae poetae ex illis arripuerunt uel sua licentia, ut scilicet metri hiatum implerent, uel etiam nulla carminis

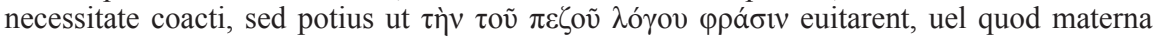
dialecto magis delectarentur; ut Aristophanes Attica, Homerus Ionica, Dorica Theocritus et Aeolica Alcaeus, quamuis uernaculae ac sibi familiari alias quoque admisceant."

12 See Antesignanus (1554, p. 12): “[...] sed Demosthenes genere Atticus, quamuis communi sermone, ut ab omnibus Graecis intelligeretur, loqui nitebatur." 
gather something that is drawn from the speech of Paris and something from that of Orléans, where they happened to serve the laws, and again something from the idiom of this or that famous city, but especially from the speech of the royal family and household. Nevertheless, they still take very special heed that they do not seem to speak in a foolish women's fashion. For if they would imitate foolish women's speech, they would be the subject of common talk for all and they would be received with the greatest laughter by the auditors. Compare now Demosthenes' speech with the speech lawyers nowadays use on the Parisian market; but compare Aristophanes' comedies with the plays of those actors who perform in their acting the customary speech of the Parisian populace.

Antesignanus thus also offers invaluable information on the sociolinguistic situation in early modern France. Because he does not seem to have visited Paris during his lifetime, it is probable that he read about the pronunciation habits of Parisian mulierculae

(1) in Desiderius Erasmus' (1466/1467/1469-1536) dialogue on Latin and Greek pronunciation (1528), ${ }^{13}$

(2) in the 1531 French grammar of Jacobus Sylvius (Jacques Dubois; 1478$1555),{ }^{14}$ or

(3) in the 1550 French grammar of Johannes Pillotus (Jean Pillot; 1515-1592). ${ }^{15}$ Of course, it may also have been an attribute of the stereotypic Parisian woman at that time.

From Antesignanus' conception of dialect and his overview of Greek dialectal features, it emerges that he saw dialectal variation as something anomalous that does not affect the common language systematically. However, this does not make it impossible to formulate certain less general rules. For Clenardus' account is sometimes followed by a scholion of Antesignanus that discusses the changes according to the "variety of dialects" (uarietas dialectorum). The differences are mainly represented as "permutations of letters" (permutationes litterarum), which consist of a limited set of types of permutations ${ }^{16}$ :

Ne uero credas ea quae hic diximus passim in omnibus dictionibus obseruari. Non enim ista locum habent, nisi in certis quibusdam uocibus et certis casibus

13 See Erasmus (1528, p. 52; italics mine): "Idem faciunt hodie mulierculae Parisinae, pro Maria sonantes Masia, pro ma mere ma mese."

14 See Sylvius (1531, p. 52; italics mine): "In utroque uitio mulierculae sunt Parrhisinae; et earum modo quidam parum uiri, dum $\mathrm{r}$ in $\mathrm{s}$ et contra Eretriensium more, $\mathrm{s}$ in $\mathrm{r}$, passim magna affectatione conuertunt, dicentes Ieru Masia, ma mesè, mon pesè, mon fresè et id genus sexcenta pro Iesu Maria, merè, perè, frerè.."

15 See Pillotus $(1550$, p. $5 \mathrm{v})$ : "R, canina littera sonum asperiorem habet, quam ut eam ferant aures Gallicae, potissimum in fine dictionum, idcirco multi pro $r$ supponunt $s$. Vbique uero id faciunt Parisinae mulierculae, quae adeo delicatulae sunt, ut pro pere dicant peze, pro mere meze." I kindly thank Professor Pierre Swiggers and one of the anonymous reviewers for drawing my attention to the relevant passages in the work of Erasmus, Sylvius, and Pillotus. See also Colombat (2003, p. 37, note 90) for these testimonies and a number of similar passages from later years.

16 This linguistic framework dates back to Marcus Terentius Varro and Trypho, both active in the first century BC (see Van Hal 2010, p. 39-40). 
partium orationis, quae per casus inflectuntur, atque in certis quibusdam personis et temporibus uerborum; [...]. Adiciemus quoque nonnullas alias regulas minus generales iuxta locorum opportunitatem. (Antesignanus 1554, p. 15)

But do not believe that these things we have said here are observed everywhere in all words. For these do not take place, except in certain words and in certain cases of the parts of speech, which are inflected through cases, and in certain persons and tenses of verbs. We will also add some other, less general rules, if the context allows it.

\section{The ANCIENT GREEK COMPONENT:}

\section{A BENCHMARK IN DISCUSSING THE CONCEPT OF DIALECT}

Antesignanus' case proves the importance of the Ancient Greek component in triggering early discussions of the dialect concept. To fully understand the notion as he conceived of it, an investigation into the classification of the Ancient Greek dialects is indispensable. In particular, I analyze both his approach to the koinè and the principle he invokes in his classification. Antesignanus also compares the Greek state of affairs to French dialectal differentiation. This raises the question as to what he considers to be the ground for the comparability of these two situations.

Following Clenardus' grammar (see note 6 above), Antesignanus (1554, p. 11) states that there are five "principal" varieties:

Quinque enim linguas praecipuas esse apud Graecos ait, utpote quae a magni nominis auctoribus fuerunt celebratae et quibus scripta paene infinita librorum uolumina posteritati reliquerunt.

For he [sc. Clenardus] says that there are five principal tongues with the Greeks, namely those that were used by the authors of great fame and in these the infinite volumes of books they have left to posterity were written.

He takes over the order of the principal Greek dialects from Clenardus: "common", "Attic", "Ionic", "Doric", and "Aeolic", which were the canonical five varieties from Roman times onwards. ${ }^{17}$ The classificatory principle underlying the propagation of these five Greek varieties is not of a linguistic, but of a literary-philological nature. These five tongues are labeled "principal", because they happened to be the linguistic equipment with which the great Greek literators gave shape to their written monuments. There were, on the other hand, many other Greek varieties (as many as there were tribes), which he calls minus praecipuae ("less principal"), as

17 See Clement of Alexandria ( $†$ before AD 215/221), Stromata 1.21.142.4 (ed. Stählin \&

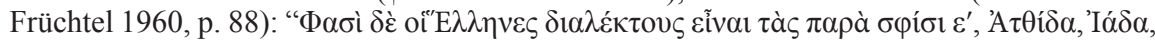

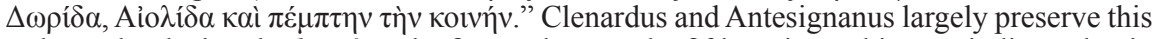
order, only placing the koine as the first and not as the fifth variety. This may indicate that in early modern times the peculiar place of the koinè was increasingly contrasted to the position of the other four dialects. The use of the term praecipuus for the principal five varieties probably goes back to the Greek grammar of Amerotius; see Amerotius (1520, p. Qiv), cited in note 18 . 
no books have survived in them. He names 13 examples: Boeotian, Sicilian, Calabrian, Cretan, Tarentine, Cyprian, Chalcidian, Macedonian, Argive, Thessalian, Laconian, Syracusan, and Pamphylian. Of these less principal dialects, only some vestiges are extant, which are preserved in the works of authors who wrote in one of the principal dialects. ${ }^{18}$ Apparently, this conception and classificatory principle greatly influenced later authors. For other important "dialectological" writers also mention it: e.g., Otho Gual(t)perius (Otto Walper; 1543-1624) in his 1589 De dialectis Graecae linguae praecipuis and Petrus Bertrandus Merigonus (Pierre Bertrand Mérigon; ca. 1586?-after 1634?) in his 1621 Facilis et compendiarius tractatus dialectorum linguae Graecae ${ }^{19}$ However, they do not mention Antesignanus explicitly, and nor do later grammarians who mention this classificatory principle. These authors, in turn, borrow it either directly from Antesignanus or indirectly through scholars such as Gualtperius and Merigonus.

Antesignanus analyzes the koinè as being constituted by the best of the four other principal varieties (see also sub 2. and Antesignanus 1554, p. 12-13). The main source of the koinè is, however, the Attic dialect:

At rursus aliqui uerbis et phrasi non minus quam rebus addicti (quales fuerunt
Demosthenes, Plato et Lucianus) non solum ad unguem communis linguae
phrasim obseruabant, sed etiam, ut communem ditare uiderentur, ex aliis
idiomatibus, praecipue ex Attico, nonnullas loquendi formulas, uel etiam
peculiares quasdam uoces, aut uocum flexus decerpebant; quae omnia tandem
temporis successu communi usu recepta sint. (Antesignanus 1554, p. 12)

But again some who are devoted to words and phrasing no less than to actual things (as, for example, Demosthenes, Plato, and Lucian) did not only perfectly observe the phrasing of the common language, but they also, so as to give the impression of enriching the common variety, gathered from the other idioms, mainly from Attic, some formulas of speaking or also some peculiar words or

18 Antesignanus (1554, p. 11): "Fuerunt uero et aliae multae, tot scilicet quot fuerunt nationes, quae Graeco sermone uterentur, ueluti Boeotica, Sicula, Regina, Cretensis, Tarentina, Cypria, Chalcidica, Macedonica, Argiua, Thessala, Laconica, Syracusana, Pamphylica; uerum minus praecipuae merito dici possunt, quod illis nulli libri, qui ad nostra usque tempora peruenerint, scripti fuerunt." See also Amerotius (1520, p. Qiv): "Graecorum linguae tot paene sunt, quot

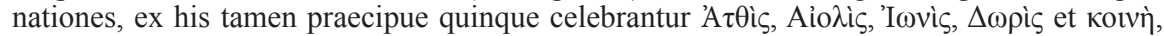
i. Attica, Aeolica, Ionica, Dorica, communis, quarum communis non alicui genti peculiaris habetur, ut ceterae, sed ea est qua communiter ac promiscue Graeci omnes utuntur."

19 See Gualtperius (1589, p. 2-3): "Primariarum autem appellationem hae merito sortiuntur, propterea quod his omnis fere Graecismus contineatur omniumque artium ac disciplinarum theoremata, rerum item praeclare gestarum historia plenissime describatur; reliquis uero libri (qui ad nos peruenerint) perscripti nulli sint ideoque temporis progressu facile collapsae fuissent, nisi ex iisdem auctores nonnulli quaedam studiose suis admiscuissent. Qua de causa et hodie plura de iis dici non possunt, quam quae ex iisdem auctoribus intelliguntur." See also Merigonus (1621, p. 3-4): "Hic uero nihil moramur multas alias dialectos (tot scilicet quot fuerunt coloniae in uarias mundi partes a Graecis missae) ueluti Boeoticam, Thessalicam, Chalcidicam, Laconicam, Cretensem, Syracusanam etc. quippe cum nulla earum monimenta ad nos usque peruenerint tantumque reperiantur quaedam uoces sparsae in libris auctorum, ut u. g. Aristophanis, propter uarias personas a se inductas in suis comoediis, superuacaneum esset eas aliis dialectis annumerare, $[\ldots] . "$ 
inflections of words; and eventually by a succession of time these were received in common usage.

To sum up, Antesignanus believes that literary authors enrich the common variety by introducing into it elegant dialectal elements that become gradually accepted.

Antesignanus also offers a window on contemporary French dialect diversity, which he discusses for the student's benefit. By being pointed to French variation, the student can adopt a referential perspective that allows him to better understand the nature of Greek dialectal diversification:

Vt autem totum huiusce rei negotium tibi ob oculos proponatur ac quid grammatici per idiomata intelligant, penitus noscas, exemplo nostri Gallici sermonis tibi paucis rem omnem aperiam. (Antesignanus 1554, p. 11)

In order that the entire fact of this matter is put before your eyes and you fully understand what the grammarians mean by "idioms", I will uncover the whole affair for you with few words by means of the example of our French speech.

He stresses the importance of the native situation to fully understand the notion of "variety of a language", terminologically encoded as dialectus, lingua, or idioma, which the grammarians use when talking about the Greek speech forms. He states that almost all people write and speak French in the area subjected to the French throne. Nevertheless, not everyone speaks as neatly as the people at the royal court and in Paris. This makes it easy to judge to which variety someone belongs, despite his exertions to avoid recognition. ${ }^{20}$ There are some exceptions, though. Some succeed in forgetting their native dialect (uernacula lingua) and in speaking neatly and purely the common French tongue. They even manage to enrich their French with some phrases and sayings derived from the dialects of the famous cities that are praised for their language. Dialects that have received general recognition can be used as "flowers" that adorn the common language. ${ }^{21}$ Now Antesignanus moves on to the Greek situation. He claims that all Greeks tried to speak and write in the common speech form, the precepts of which are now transmitted in grammatical writings. Nevertheless, everyone retained particularities from his native dialect (proprium ac maternum idioma), as for example Hippocrates, who

20 See sub 2., note 10, and Antesignanus (1554, p. 11): "Quotquot hodie in foris iudicialibus ditioni Regis subditis uersantur, neque solum ibi, sed passim inter omnes ferme non omnino obscuros homines, Gallice scribunt ac loquuntur; non tamen omnes ita terse, ut ii qui Regis aedes aut Parisiense forum frequentant; ut iudicatu difficile non sit (si quis eos loquentes audiat, uel eorum scripta legat) ad quod idioma illorum sermo accedat."

21 See note 10 above and Antesignanus (1554, p. 11-12): "Vix enim fieri potest, quin aliquid e propria siue materna lingua retineant, etiam illis inuitis ac Gallica lingua loqui nitentibus; sunt tamen aliqui maximo ingenii acumine praediti, qui quasi uernaculae linguae obliti, terso ac puro sermone utuntur; immo peculiares quasdam phrases ac dicendi modos ex famosarum et in Gallico sermone magis probatarum urbium dialectis ueluti Atticismos obseruant, quibus quasi quibusdam flosculis non raro sua scripta ornatiora reddunt." 
exhibited features from his native Ionic. ${ }^{22}$ Antesignanus also mentions Atticisms as the features par excellence for the enrichment of the common Greek language. He is thus clearly relying on his contemporary French situation to explain the internal diversification of Greek. He falls back on a similar strategy to approach diaphasicdiastratic variation in Greek, a passage I have discussed earlier (see sub 2.). On the other hand, the very fact that he is trying to clarify the Greek situation forces him to project his own interpretation of the Greek prototype on his contemporary French state of affairs. What is most remarkable within this context is Antesignanus' apparently original claim that French has certain generally recognized dialects that can enrich the common language. Thus, Antesignanus is to a certain extent in accordance with Pierre de Ronsard's (1524-1585) idea that dialect words can enrich the French common language (françois). ${ }^{23}$ However, Ronsard, who also refers to the Greek context, does not explicitly state that there are generally recognized dialects. For he merely asserts that - in specific circumstances - certain "good" elements (words) may be taken over from the dialects into the common language.

From the abovementioned data we may conclude that there is a rather ambiguous interplay between the Greek model and the French situation in Antesignanus' perception. Figure 1 aims to depict this interaction.

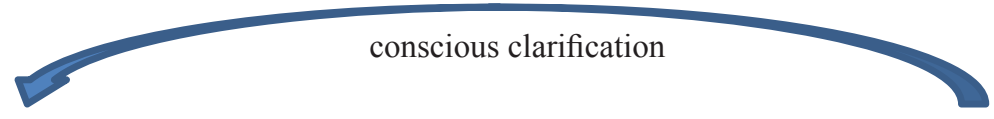

GREEK PROTOTYPE

FRENCH DIALECT SITUATION

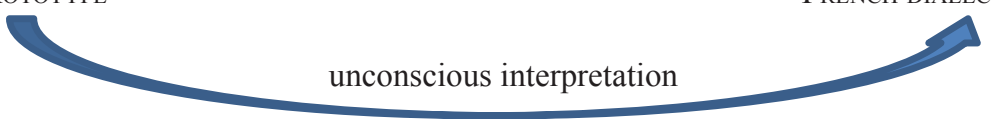

Figure 1: Antesignanus' perception of the relationship between Greek and French variation

Antesignanus uses the French situation to clarify the Greek state of affairs, apparently without realizing, however, that his view on Greek diversity is partially determining his view on French differentiation and, consequently, his clarification of

22 It is probable, however, that Hippocrates' native speech was a variety of Doric and not of Ionic, because Cos was originally a Doric island (see Colvin 2007, p. 61). It nevertheless came to be profoundly influenced by Ionic culture.

23 See Ronsard (1565, p. 4v-5r): "Tu sçauras dextrement choisir et approprier à ton œuure les mots plus significatifs des dialectes de nostre France, quand mesmement tu n'en auras point de si bons ny de si propres en ta nation et ne se fault soucier si les vocables sont Gascons, Poiteuins, Normans, Manceaux, Lionnois ou d'autre païs, pourueu qu'ilz soyent bons et que proprement ilz signifient ce que tu veux dire, sans affecter par trop le parler de la court, lequel est quelquesfois tresmauuais pour estre le langage de damoiselles et ieunes Gentilz hommes qui font plus de profession de bien combattre que de bien parler." See, e.g., Chaurand (1969, p. 64), Picoche (1973, p. 8-9), and Leclerc (2014). See also the Suravertissement au Lecteur in Ronsard (1550), where he justifies his usage of dialect words (with reference to the Greek poets, especially Theocritus). 
Greek variation. An alternative way of approaching this interaction is in terms of a process of "mutual reinforcement". Both situations are similar to a certain degree, but differences are suppressed so as to stress the similarities. The alleged basis for comparability is that both Greek and French have a common speech form, several linguistic varieties, and some generally recognized dialects, by which the common speech can be enriched.

\section{Contextualizing Antesignanus’ theorizing on Dialect}

AND RELATED NOTIONS

For an understanding of Antesignanus' concept of dialect and related notions, it is indispensable to contextualize his views. In doing so, I take his motives to tackle this problem as a starting point. I also briefly investigate both the (kind(s) of) sources Antesignanus relied on and the later fate of his conceptions.

Antesignanus' motives for discussing the concept seem quite clear. In general, his notes serve as a companion to and expansion of Clenardus' grammar. In particular, he is giving more information on the "five principal languages of the Greeks" (quinque Graecorum linguae praecipuae), to which Clenardus had only briefly referred (see sub 1.). In his formulation and definition of dialectus and the following conceptual discussion, Antesignanus seems to be original. For, although he refers to other "grammarians", I have not discovered any straightforward sources so far. It seems probable that he is paraphrasing what he has read elsewhere, elaborating upon the concept along the way. In any case, the interest in the concept of dialect was steadily growing around that time. This is shown by, among other things, Conrad Gesner's (1516-1565) discussion of the term dialectus in his famous Mithridates, which was published one year after Antesignanus' commentary on Clenardus. Contrary to Antesignanus, Gesner $(1555$, p. 1v-2r) is, for the greater part, merely translating from Clement of Alexandria (Stromata 1.21.142.1-4; ed. Stählin \& Früchtel 1960, p. 88). ${ }^{24}$ However, Gesner (1555, p. 2r) does add the following:

Nos dialectum [...] significare obseruauimus [...] alias (apud grammaticos praesertim) linguae alicuius siue in singulis siue in pluribus uerbis proprietatem, qua a communi uel reliquis similibus aut cognatis differt.

We have observed that elsewhere (mainly with the grammarians) "dialect" signifies a peculiarity of a certain language, either in separate or in several words. By this peculiarity, it differs from the common [variety] or from other similar or cognate [varieties]..$^{25}$

24 Antesignanus may also have known these passages from Clement's Stromata (see sub 3. and note 17).

25 See Colombat \& Peters (2009, p. 30-33) for a discussion of Gesner's usage and interpretations of the term dialectus. Gesner also describes a wide range of Ancient Greek dialects in his alphabetical language catalogue: see, e.g., Gesner (1555, p. 5v-6r) for Aeolic and Gesner $(1555$, p. $58 \mathrm{r})$ for Laconian. 
Very much like Antesignanus, Gesner refers to the meaning of dialectus as it is used by the grammatici. Moreover, Gesner's phrasing ("[...] linguae [...] proprietatem, qua [...] differt") also shows a striking similarity to Antesignanus' definition ("[...] sermonis quandam proprietatem, qua distinguitur [...]"). This might be a coincidence, of course. Yet it is not altogether inconceivable that Gesner knew Antesignanus' scholia. There are, however, no other indications of such an influence.

For his discussion of Greek dialectal particularities, Antesignanus is clearly relying on earlier work, because he is quoting the typical and widely known examples. He appears to fall back on Byzantine treatises (the canonical three consisting of John Philoponus, pseudo-Plutarch, and Gregory of Corinth; see Trovato 1984, appendix \& Van Rooy forthcoming) and probably also on Renaissance grammarians both from Greece and from Western Europe. The latter seems to be clear from his insertion of tables to present dialectal changes. This methodologicaltypographical innovation appears to have been initiated by Hadrianus Amerotius (Adrien Amerot; ca. 1490s-1560) in his influential treatise on the Greek dialects. This was first published as a part of his 1520 grammar, but from 1530 onwards it was edited separately (see Hoven 1985, p. 1-19 \& Hummel 1999). Compare, e.g., Amerotius' (1520, p. Piv) schematic presentation of dialectal personal pronoun variation with Antesignanus' (1554, p. 14) schematic presentation of Aeolic dialectal features. It must be granted that Amerotius' approach is different from that of Antesignanus, as the former discusses dialect peculiarities per part of speech (in which he is original), whereas the latter presents the particularities per dialect (following the tradition of Byzantine grammarians). This innovation in the presentation of the data was stimulated by the printing press and contrasts with Byzantine discussions of the dialects, which are always construed linearly (without tables). ${ }^{26}$

In the 16th century alone, Clenardus' grammar with Antesignanus' scholia received at least 55 different editions, which were issued in several important European cities such as Antwerp, London, Paris, and Venice. This way, Antesignanus' concept of "linguistic variety" could reach a wide public, which it certainly seems to have done. I have already mentioned his influential classificatory principle in approaching the Greek dialects (namely the possession of a great literature; see $s u b$ 3.). Furthermore, in his Greek grammar that was widely used in early modern Jesuit schools, Jacobus Gretserus (Jakob Gretser; 1562-1625) explicitly mentions that he is following Antesignanus' method. ${ }^{27}$ There were, however, also scholars

26 I am only referring to the presentation of dialectal features; for tables already occur in earlier manuscripts and printed books to visualize other aspects of (Greek and Latin) grammar, as rightly pointed out by one of the anonymous reviewers.

27 See Gretserus (1593, p. 5r): "Dialectos porro non in unum cumulum, ut ita loqui liceat, coniecimus, sed suo quasque loco collocauimus imitati Antesignanum. Nam ut membrum in corpore, tunc corpus ornat, si suum locum obtineat, ita et dialecti in hoc grammatico corpore. Qui uero diuersa consilia secuti, dialectos propria statione auulsas, in unum caput congerunt, 
who attacked Antesignanus' ideas, the most prominent of whom was the famous printer and grammarian Henricus Stephanus (Henri Estienne; 1528/1531-1598). For, in his often overlooked Paralipomena grammaticarum Graecae linguae institutionum, he criticizes Antesignanus' command and grammatical description of the Greek language in general and his view on the koinè in particular. The very fact that he feels the need to systematically counter Antesignanus' views may be taken to confirm the influence of the latter's scholia.

First, Stephanus rejects Antesignanus' presentation of Ancient Greek by mockingly relying on the concept of dialect. He repudiates Antesignanus for attributing fictitious forms or particularities to the Greek language or - in other words - for inventing a dialectus Antesignanica, "an Antesignanic dialect":

Magnus enim ibi est catalogus thematum, quae cum ille usitata esse dicat, sed parum, contra tamen, paucissimis exceptis, omnino sunt inusitata; adeo ut tu cum tuo praeceptori fidem adhibens ea usurpabis, ridendum te iis qui uel minimum in Graeca lingua sunt exercitati, sis propinaturus. Nam ibi cum alia

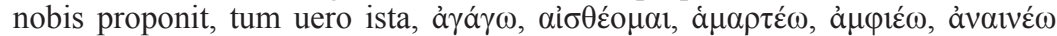
(obserua quam multa e barytonis circumflexa faciat, sicut et in aliqua eorum

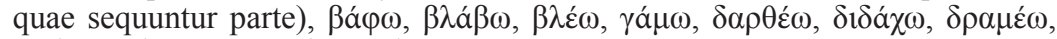

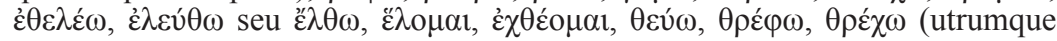

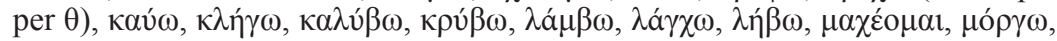
$\pi \varepsilon \pi \imath \theta \varepsilon \dot{\varepsilon} \omega$. Cuius dialecti sunt haec uerba? Antesignanicae. Quid? Illa dialectus ex barytonis circumflexa facit? Facit certe, ut uides. Litteram $v$ intericit? Ita:

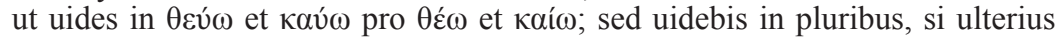
pergas; nam itidem $\pi \lambda \varepsilon v ́ \omega$ et $\pi v \varepsilon v ́ \omega$ inuenies pro $\pi \lambda \varepsilon \dot{\varepsilon} \omega$ et $\pi v \varepsilon \dot{\omega} \omega$. Habere uero eam et alia multa sibi peculiaria, tum ex his cognosces, tum ex reliquis quae tibi apud eum uidenda relinquo (Stephanus 1581, p. ๆ.viir-viiv).

For there [sc. in Antesignanus' De thematis uerborum et participiorum inuestigandi ratione libellus], there is a large catalogue of primary verbs. And even though he says that these are frequently used, they are nevertheless still, with very few exceptions, wholly unusual - to such an extent that, when you put trust in your teacher and use them, you will become the object of ridicule for those who are even least of all practiced in the Greek language. For he

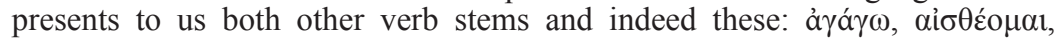

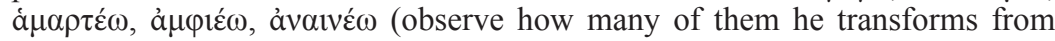
barytone to circumflex verbs, as also in a number of those that follow), $\beta a ́ p \omega$,

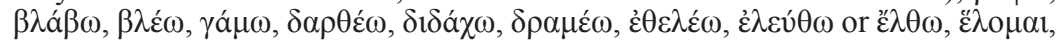

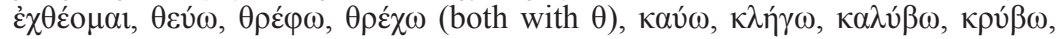

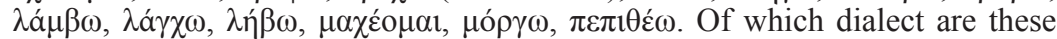
verbs? Of the Antesignanic. What? Does that dialect forge circumflex verbs from barytone verbs? It certainly does, as you see. Does it interject the letter $v$ ?

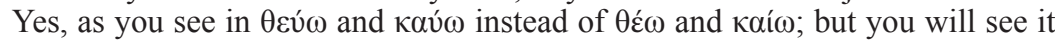
in many more verbs, if you would go further. For in like manner you will find $\pi \lambda \varepsilon v \dot{\omega} \omega$ and $\pi v \varepsilon v ́ \omega$ instead of $\pi \lambda \varepsilon \dot{\varepsilon} \omega$ and $\pi v \varepsilon \dot{\varepsilon} \omega$. But it also has many other elements particular to it, as you will recognize from these as well as from the remaining things, which I leave up to you to see with him.

illi mihi $\pi \alpha v \sigma \pi \varepsilon \rho \mu \alpha^{\alpha} \alpha$ quandam Anaxagorae moliri uidentur, cui iure optimo adscribant duo

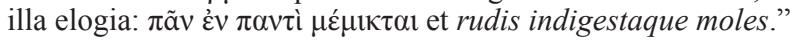


Stephanus' interpretive starting point is the dialectal reality of Ancient Greek and the fact that certain particularities can be attributed to each of the existing dialects. But as he is unable to assign to a Greek variety the forms Antesignanus ascribes to Ancient Greek, he ironically claims the existence of an "Antesignanic dialect", which deceives and confuses students of the Greek language - up to the point that they become an object of ridicule even for those having only a mediocre knowledge of Greek. ${ }^{28}$ Elsewhere, Stephanus jestingly states that Antesignanus is the "leader" (the meaning of Latin antesignanus) of the audacious and foolish grammarians of the Greek language. ${ }^{29}$

Second, after having respectfully refuted Angelus Caninius' (Angelo Canini; 1521-1557) conception of the koinè ${ }^{30}$ Stephanus attacks Antesignanus' assertion that Demosthenes and Aristophanes wrote in the koinè, a view about which he is much less mild:

Absit tamen ut Antesignano potius quam illi assentiar, dicenti Demosthenem et Aristophanem, licet Attice locuti dicantur, communi sermone scripsisse. Immo uero Attice scripsit uterque; sed Aristophanes in nonnullis etiam quae leuiora sunt, sermonis Attici consuetudinem magis seruat quam Demosthenes. (Stephanus 1581, p. 37)

But far be it that I agree with Antesignanus more than with him [sc. Caninius], as Antesignanus states that Demosthenes and Aristophanes, although they are said to have spoken Attic, wrote in common speech. On the contrary, both of them wrote in Attic; but Aristophanes preserves even in some rather trivial aspects the usage of Attic speech more than Demosthenes.

Stephanus argues that both authors wrote in Attic, but that Aristophanes preserves more Attic particularities in his plays than Demosthenes in his speeches. There are therefore different degrees of Atticism (without the Attic character vanishing). Moreover, it is possible that Attic and the koine entirely overlap. ${ }^{31}$ Stephanus' conclusion seems to have been that the intersection of Attic with the koinè is larger in the usage of Demosthenes than in that of Aristophanes, who preserves more details that are exclusively Attic. The existing overlaps between both speech forms do not, however, imply that they wrote in the koinè, as Antesignanus propounds.

28 Reference is made to Antesignanus' De thematis uerborum et participiorum inuestigandi ratione libellus, first published in the 1557 Lyon edition (see sub 1.).

29 See Stephanus (1581, p. ๆ.iiiiv): "Eorum porro quos dixi maiore audacia uel potius temeritate quam Graecae linguae cognitione instructos ad scribendam grammaticen accessisse, antesignanum dicere non dubitauerim Petrum Antesignanum; quippe qui non solum in Scholiis quae in Clenardum scripsit, sed in Praxi quoque (ut ipse nominauit) multa scripserit quae commenta potius quam commentationes uocare decet, nonnulla uero quae etiam homine mediocriter huius linguae perito indigna esse mecum fatebuntur qui uel paucas horas in iis serio examinandis posuerint."

30 See Caninius (1555, p. a3v): "Communis dialectus dicitur, non qua aliqua natio aut scriptor utatur, sed quae uerba ab aliis non immutantur, ea ad communem dialectum referenda sunt, ut ä $\rho \tau o \varsigma, \chi \rho v \sigma o ̀ \varsigma, ~ \lambda \varepsilon ́ \gamma \omega, \gamma \rho a ́ \varphi \omega$ aliaque generis eiusdem.”

31 See Stephanus (1581, p. 11): "Communis uero lingua ex singulis aliqua sumit, sed praecipue ex Attica; adeo ut illa in multis nullo ab hac discrimine separetur.” 


\section{CONCLUSION}

The present contribution had a double aim. First, I presented a descriptive-analytical overview of Antesignanus' conception of dialect and related notions. He clearly regarded a dialectus (synonyms: idioma \& lingua) as a form of speech that is determined diatopically and ethnically and thus reveals a speaker's provenance. This notion was opposed and subordinated to another linguistic entity, the lingua communis. Antesignanus' discussion was indisputably triggered by the Ancient Greek context, which he needed to clarify for his intended (i.e. French-speaking) readership by referring to variation within the French vernacular. A brief contextualization not only allowed us to offer some indications about his sources, but also about his undeniable influence and his Wirkungsgeschichte. Second, I provided a glimpse of the enormous terra incognita of early modern theorizing on the notion of dialect in general and its Ancient Greek background in particular. For Antesignanus' scholia take an important place in a more extensive research project that investigates the coming into being of the conceptual pair "language" and "dialect" (still problematic in present-day linguistics) and the constitutive importance of the early modern period in this regard. ${ }^{32}$ The most important research questions raised within the framework of this project were mentioned in sections 2.-4. ${ }^{33}$

32 See Van Hal (2010, p. 471, note 204), who signals this research lacuna. Important pioneering contributions are Alinei (1981 [1984]), Trovato (1984), Blank (1996), Werlen (1996), Burke (2004), and Haßler (2009). Two different types of texts constitute the core corpus of the project: (1) writings that consider the relevant notions on a general conceptual level and (2) texts specifically focusing on the Ancient Greek dialect context. The reasons for this focus are evident. First, the Greek language is the source for the term "dialect". Second, early modern scholars often used the Greek context as a model for their conceptualization of local speech varieties as opposed to "(standard) languages" and other notions (as I have shown for the case of Antesignanus in this paper). I take 1477/1478 as the starting point, at which time Johann[es] Reuchlin (1450-1522) "wrote" the very first Western European treatise on the Greek dialects (see Van Rooy 2014 for an edition and discussion). The chronological end point is 1782, in which year two important texts were published: (1) Friedrich Gedike's (1754-1803) Ueber die Dialekte, besonders die griechischen and (2) Johannes Friedericus Facius' (1750-1825) Compendium dialectorum Graecarum.

33 Other somewhat more marginal research questions (to which Antesignanus offers no (elaborate) answers) include:

(1) What is the early modern history of specific Greek dialect particularities? E.g., the history of views on the Aeolic digamma, which is invoked as an etymological tool in explaining certain linguistic features both cross-dialectally and cross-linguistically. See, e.g., Schmidt $(1604$, p. ):(3v-):(4r) for this principle in a cross-dialectal context.

(2) How do the source texts evaluate Ancient and vernacular Greek (and other) dialects and on which data do they rely? E.g., early modern Athenian is sometimes considered the vile aesthetic opposite of elegant ancient Attic; see the views of Theodosius Zygomalas (1544-1607) in Crusius (1584, p. 216).

(3) Are there recurrent themes/topoi? E.g., the regional-administrative entity of the prouincia ("province") is often tied up with the notion of dialect. See, e.g., Bibliander (1548, p. 19). 


\section{REFERENCES}

\section{Primary sources}

Amerotius, Hadrianus, 1520. Compendium Graecae grammatices, perspicua breuitate complectens, quicquid est octo partium orationis, Louanii, apud Theodoricum Martinum Alostensem.

- 1530. De dialectis diuersis declinationum Graecanicarum tam in uerbis quam nominibus, ex Corintho, Ioan. Grammatico, Plutarcho, Ioan. Philopono atque aliis eiusdem classis, Parisiis, ex officina Gerardi Morrhii Campensis.

Antesignanus, Petrus , 1554. "De dialectis appendix", in Clenardus \& Antesignanus (1554), 11-16.

— (ed.), 1556. Terentius. Dictionibus hyperdisyllabis a P. Antesignano Rapistagnensi affixi sunt in puerorum gratiam natiui accentus; atque ad marginem apposita est singulorum uersuum dimensio non minus utili quam artificiosa methodo litteris et notis breuissimisque scholiis designata. Litterarum et notarum explanatio praefatione continetur, Lugduni, apud Matthiam Bonhomme.

Bibliander, Theodorus, 1548. De ratione communi omnium linguarum et litterarum commentarius Theodori Bibliandri, Tiguri, apud Christoph. Frosch.

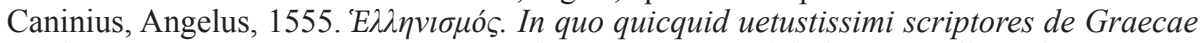
linguae ratione praecipiunt atque adeo omnia quae ad dialectos intelligendas et poetas penitus cognoscendos pertinent, facili methodo exponuntur. Eo accedit plurimorum uerborum originis explicatio, Parisiis, apud Guil. Morelium.

Clenardus, Nicolaus, 1530. Institutiones in linguam Graecam, Louanii, ex officina chalcographica Rutgeri Rescii ac Ioannis Sturmii.

Clenardus, Nicolaus, and Antesignanus, Petrus, 1554. Institutiones linguae Graecae, N. Cleonardo auctore, cum scholiis P. Antesignani Rapistagnensis, Lugduni, apud Matthiam Bonhomme.

- 1557. Institutiones ac meditationes in Graecam linguam, N. Clenardo auctore, cum scholiis et Praxi P. Antesignani Rapistagnensis. [...], [altera editio], Lugduni, apud Matthiam Bonhomme.

Costus, Petrus, 1554. קהלת תרגום. Targum koheleth, hoc est Caldaica paraphrasis ecclesiastis, Latina facta, [...]. Cui Salomonis Ecclesiastem ex translatione uulgata aduersum posuimus. Accessit epistola in eandem sententiam, Lugduni, apud Matthiam Bonhomme.

Crusius, Martinus, 1584. Turcograeciae libri octo, Basileae, per Leonardum Ostenium, Sebastiani Henricpetri impensa.

Erasmus, Desiderius, 1528. De recta Latini Graecique sermonis pronuntiatione [...] dia$\log u s$, apud inclytam Basilaeam, in officina Frobeniana.

Facius, Johannes Friedericus, 1782. Compendium dialectorum Graecarum, Norimbergae, sumptibus E. C. Grattenaueri.

Gedike, Friedrich, 1782. "Ueber Dialekte, besonders die griechischen", Berlinsches Magazin der Wissenschaften und Künste 1/2, 1-26.

Gesner, Conrad, 1555. Mithridates. De differentiis linguarum tum ueterum tum quae hodie apud diuersas nationes in toto orbe terrarum in usu sunt, [...] obseruationes, Tiguri, excudebat Froschouerus.

Gretserus, Jacobus, 1593. Institutionum de octo partibus orationis, syntaxi et prosodia Graecorum libri tres, Ingolstadii, excudebat Dauid Sartorius.

Gualtperius, Otho, 1589. De dialectis Graecae linguae praecipuis, Attica, Ionica, Dorica, Aeolica et coronidis uice nonnulla de proprietate poetica. Libellus methodice conscriptus et in gratiam tironum $\varphi \imath \lambda \varepsilon \lambda \lambda \eta v \omega v$ in Academia Marpurgensi propositus, Francofurti ad Moenum, ex officina typographica Ioannis Spiessii.

Merigonus, Petrus Bertrandus, 1621. Facilis et compendiarius tractatus dialectorum linguae Graecae. Vna cum tabulis illarum, quibus accessit alia tabula licentiam poetarum complectens, perquam utilis studiosis poeticae lectionis. [...]. Cum indice eorum quae continentur in hoc tractatu, Parisiis, sumptibus auctoris. 
Pillotus, Johannes, 1550. Gallicae linguae institutio, Latino sermone conscripta, Parisiis, ex officina Stephani Groulleau.

Ronsard, Pierre de, 1550. Les quatre premiers liures des Odes, Paris, chez Guillaume Cauellart.

- 1565. Abbregé de l'art poëtique François, A Paris, chez Gabriel Buon.

Schmidt, Erasmus, 1604. Tractatus de dialectis Graecorum principalibus, quae sunt in parte $\lambda \hat{\varepsilon} \xi \varepsilon \omega \varsigma$. Cum rerum et uerborum indice locupletissimo. Ex optimis grammaticis, methodo discentibus aptissima dispositus, Wittebergae, imprimebat Laurentius Seuberlich, impensis Samuel Selfisch.

Stählin, Otto (ed.), 1960. Clemens Alexandrinus. Zweiter Band. Stromata Buch I-VI, in dritter Auflage neu herausgegeben von Ludwig Früchtel, Berlin, Akademie Verlag (Die griechischen christlichen Schriftsteller der ersten Jahrhunderte 52/2).

Stephanus, Henricus, 1581. Paralipomena grammaticarum Graecae linguae institutionum. Item animaduersiones in quasdam grammaticorum Graecorum traditiones, [Geneuae], [excudebat Henricus Stephanus].

Sylvius, Jacobus, 1531. In linguam Gallicam isagwge, una cum eiusdem grammatica Latino-Gallica, ex Hebraeis, Graecis et Latinis auctoribus, Parisiis, ex officina Roberti Stephani.

\section{Secondary sources}

Alinei, Mario, 1984. “1. 'Dialetto'. Un concetto rinascimentale fiorentino”, Lingua e dialetti: struttura, storia e geografia, Bologna, Il Mulino (Studi linguistici e semiologici), 169-199. [= Alinei, Mario, 1981. "Dialetto: un concetto rinascimentale fiorentino. Storia e analisi", Quaderni di Semantica 2, 147-173.]

Bayle, Pierre, 1740. "Antesignan (Pierre)", Des Maizeaux (ed.), Dictionnaire historique et critique, cinquième édition, revue, corrigée et augmentée; avec la vie de l'auteur, A Rotterdam, Leide, La Haye et Utrecht, chez P. Brunel et alii; Samuel Luchtmans; P. Gosse et alii; Etienne Neaulme, vol. 1/1 [A-B], 243-244.

Blank, Paula, 1996. Broken English. Dialects and the Politics of Language in Renaissance Writings, London \& New York, Routledge (The Politics of Language).

Burke, Peter, 2004. Languages and Communities in Early Modern Europe, Cambridge, Cambridge University Press.

Chaix, Paul, 1954. Recherches sur l'imprimerie à Genève de 1550 à 1564. Étude bibliographique, économique et littéraire, Genève, Droz (Travaux d'Humanisme et Renaissance 16).

Chaurand, Jacques, 1969. Histoire de la langue française, Paris, Presses Universitaires de France ("Que sais-je?" Le point des connaissances actuelles 167).

Colombat, Bernard (ed.), 2003. Jean Pillot. Institution de la langue française / Gallicae linguae institutio (1561), Paris, Honoré Champion (Textes de la Renaissance. Série Traités sur la langue française 72).

Colombat, Bernard, and Peters, Manfred, 2009. "Introduction", Colombat, Bernard and Peters, Manfred (eds.), Conrad Gessner. Mithridate / Mithridates (1555), Genève, Droz (Travaux d'Humanisme et Renaissance 452), 11-90.

Colvin, Stephen, 2007. A Historical Greek Reader. Mycenaean to the Koiné, Oxford, Oxford University Press.

Haag, Eugène, and Haag, Émile, 1886. "Davantes (Pierre)", La France protestante, deuxième édition (dir. Henri Bordier), Paris, Fischbacher, vol. 5, 163-170.

Haßler, Gerda, 2009. "Dialekt", Haßler, Gerda and Neis, Cordula (eds.), Lexikon sprachtheoretischer Grundbegriffe des 17. und 18. Jahrhunderts, Berlin, De Gruyter, vol. 1, 866-882.

Haugen, Einar, 1966. “Dialect, Language, Nation”, American Anthropologist 68/4, 922-935.

Hayaert, Valérie, 2008. Mens emblematica et humanisme juridique. Le cas du Pegma cum narrationibus philosophicis de Pierre Coustau, 1555, Genève, Droz (Travaux d'Humanisme et Renaissance 438). 
Hoven, René, 1985. Bibliographie de trois auteurs de grammaires grecques contemporains de Nicolas Clénard. Adrien Amerot, Arnold Oridryus, Jean Varennius, Aubel, Gason (Livre - Idées - Société 7).

- 1993. "De Europese uitstraling van Cleynaerts' Griekse spraakkunst", Tournoy, G., Tulkens, J., and Ilegems, M. (eds.), Nicolaes Cleynaerts (1493-1993). Van Diest tot Marokko. Catalogus van de Cleynaertstentoonstelling in het Stedelijk Museum te Diest, juli-oktober 1993, Brussel, Dienst voor geschiedkundig en folkloristisch onderzoek van de provincie Brabant (De Brabantse folklore en geschiedenis 278-279), 123-132.

Hummel, Pascale, 1999. "Un opuscule-relais. Le De dialectis (1520/1530) d'Adrien Amerot", Bibliothèque d'Humanisme et Renaissance. Travaux et documents 61/2, 479-494.

Leclerc, Jacques, 2014. "La Renaissance. L'affirmation du français ( $\mathrm{XvI}^{\mathrm{e}}$ siècle)", L'aménagement linguistique dans le monde, Québec, TLFQ [Université Laval]. [consulted: September 16, 2014. <http://www.axl.cefan.ulaval.ca/francophonie/HIST FR s5 Renaissance.htm $>$.]

Marty, Emile, 1896. "La patrie de Pierre Davantès connu sous le pseudonyme d'Antesignan", Revue historique, scientifique et littéraire du département du Tarn (ancien pays d'Albigeois) 13, 346-351.

Picoche, Jacqueline, 1973. "Les monographies dialectales (domaine gallo-roman)", Langue française 18/1, 8-41.

R.I.E.C.H (Répertoire des imprimeurs et éditeurs suisses actifs avant 1800) [consulted: September 23, 2014. <http://dbserv1-bcu.unil.ch/riech/intro.php $>$.]

Schwarzfuchs, Lyse, 2008. L’hébreu dans le livre lyonnais au XVI' siècle. Inventaire chronologique, Lyon, ENS \& Institut d'histoire du livre.

Swiggers, Pierre, and Van Hal, Toon, 2009. "Nicolas Clenardus", Stammerjohann, Harro (ed.), Lexicon Grammaticorum. A Bio-Bibliographical Companion to the History of Linguistics, second edition, revised and enlarged, Tübingen, Niemeyer, vol. 1, 308-309.

Trovato, Paolo, 1984. “'Dialetto' e sinonimi ('idioma', 'proprietà', 'lingua') nella terminologia linguistica quattro- e cinquecentesca (con un'appendice sulla tradizione a stampa dei trattatelli dialettologici bizantini)", Rivista di letteratura italiana 2, 205-236.

Van Hal, Toon, 2010. "Moedertalen en taalmoeders". Het vroegmoderne taalvergelijkende onderzoek in de Lage Landen, Brussel, Koninklijke Vlaamse Academie voor Wetenschappen en Kunsten (Verhandelingen van de Koninklijke Vlaamse Academie van België voor Wetenschappen en Kunsten. Nieuwe Reeks 20).

Van Rooy, Raf, 2014. "A first stumbling step toward Ancient Greek dialectology in Western Europe. An edition and brief discussion of Johann Reuchlin's De quattuor Graecae linguae differentiis libellus (1477/1478)", Bibliothèque d'Humanisme et Renaissance. Travaux et documents 76/3, 501-526.

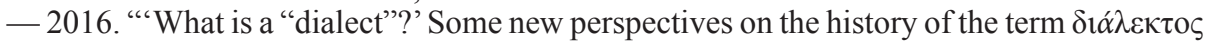
and its interpretations in ancient Greece and Byzantium", Glotta 92, 244-279.

- (Forthcoming) "«Plutarque dialectologue ». La pseudo-autorité de Plutarque dans le discours sur les dialectes grecs à la Renaissance (ca. 1400-1670), Belgisch Tijdschrift voor Filologie en Geschiedenis / Revue Belge de Philologie et d'Histoire".

Werlen, Iwar, 1996. "6. Dialektologie und Sprachgeographie vom 13. bis 20. Jahrhundert", Schmitter, Peter (ed.), Sprachtheorien der Neuzeit II. Von der Grammaire de Port-Royal (1660) zur Konstitution moderner linguistischer Disziplinen, Tübingen, Gunter Narr (Geschichte der Sprachtheorie 5), 427-458. 